STUDIA Z PRAWA WYZNANIOWEGO

Tom $24-2021$

DOI: https://doi.org/10.31743/spw.12997

MICHAŁ OŻÓG*

\title{
ZWALCZANIE CHORÓB ZAKAŹNYCH W STANIE EPIDEMII ORAZ W STANIE KLĘSKI ŻYWIOŁOWEJ A REALIZACJA WOLNOŚCI SUMIENIA I RELIGII W ŚWIETLE KONSTYTUCJI RZECZYPOSPOLITEJ POLSKIEJ Z DNIA 2 KWIETNIA 1997 ROKU I USTAWODAWSTWA
}

Combating infectious diseases during a state of epidemic and state of natural disaster and the realization of the freedom of conscience and religion in the light of the Constitution of the Republic of Poland of April 2, 1997 and the legislation

Streszczenie: Przedmiotem artykułu jest przedstawienie statusu prawnowyznaniowego człowieka w stanie epidemii oraz w stanie klęski żywiołowej. Celem opracowania jest dokonanie oceny występujących rozwiązań ustawowych z punktu widzenia modelu ustrojowego ochrony wolności sumienia i wyznania. Artykuł zawiera ogólną charakterystykę reżimu prawnego stanu epidemii oraz stanu klęski żywiołowej wraz z analizą i oceną przesłanek ustawowych wprowadzenia tych stanów funkcjonowania państwa. Zwrócono szczególną uwagę na problem zbiegu praw i wolności konstytucyjnych, gdy do realizacji wolności sumienia i religii potrzebne są inne prawa człowieka, które mogą zostać ograniczone w stanie epidemii oraz w stanie klęski żywiołowej. W badaniach wykorzystano metodę dogmatyczno-prawną. Ocena regulacji prawnych obejmuje także kwestie związane z wyborem właściwej metody legislacyjnej. Przeprowadzone analizy prowadzą do wniosku, że wolność sumienia i religii nie jest należycie chroniona na gruncie obowiązujących przepisów o stanie epidemii i stanie klęski żywiołowej. Tekst zawiera propozycję określonych zmian legislacyjnych w kierunku wzmocnienia poziomu ochrony wolności sumienia i religii w ustawodawstwie zwykłym.

* Dr, Pracownia Systemów Politycznych, Katedra Prawa Konstytucyjnego i Systemów Politycznych, Wydział Prawa, Uniwersytet w Białymstoku, ul. Mickiewicza 1/218, 15-213 Białystok, e-mail: m.ozog@uwb.edu.pl. ORCID 0000-0002-4315-5235. 
Słowa kluczowe: epidemia; stan klęski żywiołowej; wolność sumienia i religii; COVID-19

Abstract: The article concerns the problem of realization of the freedom of conscience and religion during a state of epidemic and state of natural disaster. The aim of this study is to assess the existing statutory solutions from the point of view of the political model of protection of the freedom of conscience and religion. The article presents general characteristics of the legal regime of a state of epidemic and state of natural disaster together with an analysis and evaluation of the statutory prerequisites for the introduction of these states. Particular attention is given to the problem of the convergence of the constitutional rights and freedoms, when the realization of the freedom of conscience and religion requires other human rights which may be restricted during a state of epidemic and state of natural disaster. The analysis was performed using the dogmatic-legal method. The evaluation of the legal regulations also concerns the issues connected with the choice of the appropriate legal method. The analysis points to the conclusion that the protection of the freedom of conscience and religion during states of epidemic and natural disaster is not ensured to a sufficient extent under current legislation. The author proposes certain legislative changes to raise the level of protection of the freedom of conscience and religion in ordinary legislation.

Key words: epidemic; state of natural disaster; freedom of conscience and religion; COVID-19

\section{WPROWADZENIE}

Pierwszy przypadek zakażenia wirusem SARS-CoV-2, który wywołuje chorobę określaną jako COVID-19, został stwierdzony w Chinach w pierwszych dniach grudnia 2019 r. ${ }^{1}$, a tzw. polskiego ,pacjenta zero” tej jednostki chorobowej odnotowano w Zielonej Górze 4 marca 2020 r. ${ }^{2}$ Wysoki poziom zaraźliwości przyczynił się do szybkiego rozprzestrzenienia się wirusa na całym świecie, co w konsekwencji doprowadziło do ogłosze-

1 Kitowska, Stępień, Rosińska, Szmulik, Jamsheer-Bratkowska, Budziosz, Sadkowska-Todys 2020, 417.

2 Tamże, 418; Ministerstwo Zdrowia, 4 marca 2020 r., Pierwszy przypadek koronawirusa $w$ Polsce, https://www.gov.pl/web/zdrowie/pierwszy-przypadek-koronawirusa-w-polsce [dostęp: 16.08.2021]. 
nia stanu pandemii przez Światową Organizację Zdrowia (World Health Organization) w dniu 11 marca $2020 \mathrm{r}^{3}$

Od samego początku obecnej pandemii we wszystkich państwach wydaje się szereg szczegółowych regulacji prawnych, które mają na celu zatrzymanie rozprzestrzeniania się wirusa SARS-CoV-2. Nie ulega jednak wątpliwości, że bieżąca działalność prawodawcza musi zawsze pozostawać zgodna z porządkiem konstytucyjnym. Należy bowiem podkreślić, że w demokratycznym państwie prawnym żadne cele nie uświęcają łamania ustawy zasadniczej. Organy władzy publicznej mają obowiązek przestrzegania obowiązującego prawa także w odniesieniu do tworzenia szczególnych regulacji prawnych w celu przeciwdziałania występowaniu i skutkom chorób zakaźnych. Unormowania wydawane w celu zwalczania transmisji koronawirusa powinny respektować standard konstytucyjny w zakresie wprowadzania ograniczeń praw i wolności człowieka i obywatela.

Prawo polskie przewiduje szczególne reżimy prawne, które mogą być wprowadzone do podejmowania działań w celu zapobiegania rozprzestrzeniania się chorób zakaźnych i przeciwdziałania ich skutkom. Są to: stan zagrożenia epidemicznego i stan epidemii ${ }^{4}$, uregulowane w art. 46 ust. 2 i 4 ustawy z dnia 5 grudnia 2008 r. o zapobieganiu oraz zwalczaniu zakażeń i chorób zakaźnych u ludzi ${ }^{5}$ oraz stan klęski żywiołowej, który unormowany został w ustawie z dnia 18 kwietnia 2002 r. o stanie klęski żywiołowej ${ }^{6}$. Ponadto regulacje dotyczące tego stanu nadzwyczajnego zawarte zostały w rozdziale XI Konstytucji Rzeczypospolitej Polskiej $\mathrm{z}$ dnia 2 kwietnia $1997 \mathrm{r}^{7}$

3 WHO Director-General's opening remarks at the media briefing on COVID-1911 March 2020, https://www.who.int/dg/speeches/detail/who-director-general-s-opening-remarks-at-the-media-briefing-on-covid-19---11-march-2020 [dostęp: 16.08.2021].

4 W dalszej części rozważań analizy dotyczące stanu epidemii odnoszą się w równym zakresie do stanu zagrożenia epidemicznego.

5 Ustawa z dnia 5 grudnia 2008 r. o zapobieganiu oraz zwalczaniu zakażeń i chorób zakaźnych u ludzi, tekst jedn. Dz. U. z 2020 r., poz. 1845, dalej: u.z.c.z.

6 Ustawa z dnia 18 kwietnia 2002 r. o stanie klęski żywiołowej, tekst jedn. Dz. U. z 2017 r., poz. 1897, dalej: u.k.ż.

7 Konstytucja Rzeczypospolitej Polskiej z dnia 2 kwietnia 1997 r., Dz. U. z 1997 r. $\mathrm{Nr} 78$, poz. 483 z późn. zm. 
Warto podjąć próbę oceny gwarancji wolności religijnej w szczególnych warunkach funkcjonowania państwa w okresie przeciwdziałania rozprzestrzenianiu się choroby zakaźnej. Od czasu wejścia w życie obowiązującej ustawy zasadniczej nie mieliśmy bowiem do czynienia z tak daleko idącymi ograniczeniami tej wolności. Potrzeba przeprowadzenia odnoszących się do tego analiz podyktowana jest przede wszystkim tym, że wolności sumienia i religii nadano szczególnie wysoką rangę w polskiej Konstytucji.

Podstawowy cel badawczy w niniejszym opracowaniu dotyczy określenia konstytucyjnego modelu gwarancji i ochrony wolności sumienia i religii w stanie epidemii oraz w stanie klęski żywiołowej, a więc podstawowych reżimach prawnych wprowadzanych w związku z przeciwdziałaniem rozprzestrzenianiu się chorób zakaźnych lub też zwalczaniem ich skutków. Natomiast inspirację stanowiły dyskusje nad zasadnością wprowadzenia w Polsce stanu epidemii albo stanu klęski żywiołowej oraz wpływem odnoszącej się do tego decyzji na możliwości realizacji wolności sumienia i religii.

Dążąc do osiągnięcia sformułowanego wyżej celu należy dokonać analizy porównawczej statusu prawno-wyznaniowego jednostki na gruncie wskazanych wyżej reżimów prawnych w ujęciu systemowym. Warto przy tym postawić pytanie o model ustrojowy ochrony wolności sumienia i religii i jego realizację $\mathrm{w}$ prawodawstwie zwykłym $\mathrm{w}$ odniesieniu do funkcjonowania państwa w warunkach szczególnych. Trzeba ocenić, w jakim zakresie obowiązujące w Polsce przepisy ustawowe odpowiadają przyjmowanym założeniom ustrojowym i aksjologicznym. Ocena tych przepisów jest szczególnie istotna $\mathrm{z}$ tego względu, że to właśnie na ich podstawie wydawane są akty wykonawcze, w których zawarte są unormowania określające status jednostki również w sferze prawno-wyznaniowej. Należy jednak poczynić zastrzeżenie, że celem niniejszego artykułu nie jest przeprowadzenie analizy konstytucyjnej polskich rozwiązań prawno-konfesyjnych uchwalonych w okresie pandemii, gdyż powyższe zagadnienie było już podejmowane w literaturze przedmiotu ${ }^{8}$.

8 Dyda, Olszówka 2020, 441-469; J. Kwaśniewski, T. Zych, M. Olszówka, K. Dyda, 16 kwietnia 2020 r., Analiza wprowadzonych $w$ zwiazku z przeciwdziałaniem epidemii koronawirusa ograniczeń wolności religii i swobody przemieszczania się w świetle standardów 


\section{OGÓLNA CHARAKTERYSTYKA REŻIMU PRAWNEGO STANU EPIDEMII ORAZ STANU KLĘSKI ŻYWIOŁOWEJ. UWAGI NA TLE DECYZJI W SPRAWIE PRZECIWDZIAŁANIA ROZPRZESTRZENIANIU SIĘ COVID-19}

Działania prawne związane ze stwierdzeniem pierwszego przypadku zakażenia wirusem SARS-CoV-2 w Polsce władze publiczne podjęły już w marcu $2020 \mathrm{r}$. We wczesnym okresie walki z koronawirusem konieczne było wydanie szczegółowych regulacji prawnych, które w swoim założeniu miały się przyczynić do zminimalizowania kontaktów społecznych i ograniczenia mobilności. Brak szczepionek oznaczał, że był to wówczas jedyny sposób przeciwdziałania transmisji tego patogenu. $\mathrm{Z}$ perspektywy prawnej pierwszorzędne znaczenie miał wybór szczególnego reżimu prawnego, który ewentualnie należało wówczas wprowadzić. Było jasne, że wybór ten będzie posiadał doniosłe konsekwencje praktyczne. Przed podobnym dylematem stanęły władze publiczne innych państw. W Polsce z dniem 14 marca 2020 r. ogłoszony został stan zagrożenia epidemicznego 9 , a następnie z dniem 20 marca $2020 \mathrm{r}$. wprowadzono stan epidemii, który trwa nadal w chwili przygotowywania niniejszego artykułu ${ }^{10}$. Posłużono się przy tym aktami wykonawczymi, które zostały wydane na podstawie przepisów art. 46 ust. 2 i 4 u.z.c.z. Podobnie postąpiono również w innych państwach europejskich, w tym we Francji, w Niemczech czy we Włoszech, gdzie zdecydowano się na rozwiązanie, zgodnie z którym organy władzy wykonawczej na mocy przepisów ustawowych podejmują działania prawne w celu zatrzymania rozprzestrzeniania się wirusa SARSCoV-2 ${ }^{11}$. W Niemczech zaś stan epidemii o zasięgu ogólnokrajowym wprowadzono na mocy aktu ustawowego. We wspomnianych państwach

Konstytucji RP i prawa międzynarodowego, https://ordoiuris.pl/wolnosci-obywatelskie/ analiza-wprowadzonych-w-zwiazku-z-przeciwdzialaniem-epidemii-koronawirusa [dostęp: 03.09.2021].

9 Zob. rozporządzenie Ministra Zdrowia z dnia 13 marca 2020 r. w sprawie ogłoszenia na obszarze Rzeczypospolitej Polskiej stanu zagrożenia epidemicznego, Dz. U. z 2020 r., poz. 433.

10 Zob. rozporządzenie Ministra Zdrowia z dnia 20 marca 2020 r. w sprawie ogłoszenia na obszarze Rzeczypospolitej Polskiej stanu epidemii, Dz. U. z 2020 r., poz. 491.

11 Bosek 2021a, 114. 
nie zdecydowano się jednak na wprowadzenie konstytucyjnego stanu nadzwyczajnego, a we Włoszech ten okres funkcjonowania państwa nie został nawet wyróżniony ${ }^{12}$.

Warto przy tym podkreślić, że „stan epidemii” oraz „stan zagrożenia epidemicznego" nie stanowią instytucji prawnych znanych Konstytucji RP (w odróżnieniu od stanów nadzwyczajnych: stanu wojennego, stanu wyjątkowego oraz stanu klęski żywiołowej, których regulacja prawna została zawarta w rozdziale XI polskiej Ustawy zasadniczej). Funkcjonowanie stanu zagrożenia epidemicznego i stanu epidemii wynika z ogólnej kompetencji prawodawczej ustawodawcy zwykłego. Z pewnością u ich podstaw stoi potrzeba ochrony zdrowia publicznego. Brak regulacji konstytucyjnej dotyczącej wprost stanu zagrożenia epidemicznego oraz stanu epidemii znajduje jednak doniosłe konsekwencje prawne. Należy bowiem podkreślić, że reżim prawa o stanach nadzwyczajnych przewiduje szczegółowe unormowania, które dotyczą m.in. zasad wprowadzania tego stanu, szczególnych zasad funkcjonowania organów władzy publicznej, ograniczeń w zakresie organizacji wyborów, zasad ponoszenia odpowiedzialności odszkodowawczej władz publicznych za wprowadzone ograniczenia konstytucyjnych praw i wolności ${ }^{13}$, zasad limitacji praw człowieka itp. ${ }^{14}$ Unormowania zawarte w rozdziale XI Konstytucji RP nie mogą być modyfikowane w ustawie o stanie klęski żywiołowej ani też w żadnych innych aktach szczegółowych. Swoboda ustawodawcy zwykłego w kształtowaniu statusu jednostki w stanie klęski żywiołowej jest więc wyraźnie ograniczona ${ }^{15}$. W art. 233 ust. 3 Konstytucji RP wskazano bowiem te prawa i wolności, które mogą zostać zawieszone w stanie klęski żywiołowej ${ }^{16}$. W wyliczeniu tym nie znalazła się wolność sumienia i religii. Oznacza to tym samym, że wolność ta w stanie klęski żywiołowej ma charakter niederogowalny. Warto również wskazać na szczególne znaczenie klauzuli antydyskryminacyjnej z art. 233 ust. 2 Konstytucji RP, zgodnie z którym ,niedopuszczalne

12 Tamże, 128.

13 Zob. ustawa z dnia 22 listopada 2002 r. o wyrównywaniu strat majątkowych wynikających z ograniczenia w czasie stanu nadzwyczajnego wolności i praw człowieka i obywatela, Dz. U. z 2002 r. Nr 233, poz. 1955.

14 Garlicki 2007, 397.

15 Skrzydło 2013, 308.

16 Wilk 2012, 145-161. 
jest ograniczenie wolności i praw człowieka i obywatela wyłącznie z powodu rasy, płci, języka, wyznania lub jego braku, pochodzenia społecznego, urodzenia oraz majątku”. Ograniczenia wprowadzane w stanie klęski żywiołowej nie mogą więc opierać się wyłącznie na kryterium wyznania ${ }^{17}$, aczkolwiek w doktrynie istnieje spór w kwestii zastosowania art. 233 ust. 2 Konstytucji RP do regulacji o stanie klęski żywiołowej ${ }^{18}$. Omawiane przepisy konstytucyjne stanowią gwarancje prawnej ochrony wolności $\mathrm{z}$ art. 53 Konstytucji RP w stanie klęski żywiołowej.

Natomiast wprowadzenie stanu zagrożenia epidemicznego lub stanu epidemii opiera się na przepisach ustawy o zapobieganiu oraz zwalczaniu zakażeń i chorób zakaźnych u ludzi. Zasady funkcjonowania organów władzy publicznej w tych warunkach funkcjonowania państwa wynikają przede wszystkim z ogólnych regulacji konstytucyjnych i przepisów tej ustawy. Dotyczy to również ograniczeń w sferze praw człowieka. Ograniczenia praw i wolności konstytucyjnych w stanie zagrożenia epidemicznego i w stanie epidemii nie są obwarowane zasadami, które dotyczą stanów nadzwyczajnych. Konieczne jest jednak zachowanie zasad ogólnych limitacji praw jednostki. Należy zatem przyjąć, że ingerencja w sferę praw człowieka w stanie epidemii musi spełniać standard konstytucyjny z art. 31 ust. 3 Konstytucji. Oznacza to, że żadne prawa i wolności konstytucyjne w stanie epidemii nie mogą zostać całkowicie zawieszone, a więc niedopuszczalne jest ustanawianie ograniczeń prowadzących do naruszenia istoty danego prawa lub wolności konstytucyjnej ${ }^{19}$. Dopuszczalność takiej ingerencji musiałaby mieć odpowiednie umocowanie w Konstytucji. W świetle treści przepisów Ustawy zasadniczej należy uznać, że wolność sumienia i religii nie może zostać całkowicie zawieszona w stanie zagrożenia epidemicznego i w stanie epidemii. Brak akceptacji ustrojodawcy dla zawieszenia wolności z art. 53 Konstytucji RP w stanach nadzwyczajnych przekonuje, iż tym bardziej będzie to niedopuszczalne w stanie zagrożenia epidemicznego oraz w stanie epidemii.

17 Winczorek 2008, 438.

18 Niektórzy autorzy wyrażają pogląd, zgodnie z którym klauzula antydyskryminacyjna z art. 233 ust. 2 Konstytucji RP nie znajduje zastosowania w stanie klęski żywiołowej z uwagi na jej usytuowanie w systematyce wewnętrznej art. 233. Por. Działocha 2005, 7; Steinborn 2016, 1632.

19 Zubik 2021, 347. 
Warto podkreślić, że ani unormowania konstytucyjne, ani też odnoszące się do tego przepisy ustawowe, nie przewidują szczególnej ochrony wolności sumienia i religii w stanie epidemii. Taki stan prawny trudno uznać za zadowalający, uwzględniając wysoką rangę wolności sumienia i religii $\mathrm{w}$ całokształcie prawno-wyznaniowych regulacji polskiej Ustawy zasadniczej. Polski ustrojodawca przywiązał bowiem do tej wolności szczególną wagę, o czym świadczy chociażby rozbudowany katalog gwarancji prawnych, zgrupowany w siedmiu jednostkach redakcyjnych art. 53 Konstytucji RP. W stanie zagrożenia epidemicznego oraz w stanie epidemii nie przewidziano kategorii niederogowalnych praw i wolności konstytucyjnych. Oznacza to, iż w tych warunkach funkcjonowania państwa wolność sumienia i religii może podlegać ograniczeniu jedynie na zasadach ogólnych. Przepisy dotyczące stanu zagrożenia epidemicznego i stanu epidemii nie zawierają ponadto szczególnej klauzuli antydyskryminacyjnej, która znajduje zastosowanie w odniesieniu do regulacji uchwalanych w reżimie stanu klęski żywiołowej. Wydaje się jednak, że z ogólnych przepisów Konstytucji RP wynika zakaz ustanawiania ograniczeń praw jednostki wyłącznie w oparciu o kryterium wyznania. Treść klauzuli konstytucyjnej z art. 32 jest bowiem szeroka i obejmuje zakaz dyskryminacji z jakiejkolwiek przyczyny.

Mając powyższe na uwadze, należy postulować de lege ferenda, aby do ustawy o zapobieganiu oraz zwalczaniu zakażeń i chorób zakaźnych u ludzi dodać rozdział dotyczący wprowadzania w tym stanie ograniczeń praw i wolności konstytucyjnych, analogicznie jak ma to miejsce w ustawie o stanie klęski żywiołowej. W przepisach rozdziału 8 u.z.c.z. (Zasady postępowania $w$ razie stanu zagrożenia epidemicznego $i$ stanu epidemii) jedynie fragmentarycznie uregulowano kwestie ograniczeń praw człowieka. Postulowana interwencja legislacyjna mogła zostać już podjęta zgodnie z potrzebą chwili. Warto wspomnieć, że na początku okresu walki z pandemią we Włoszech dokonano zmiany prawa i na podstawie dekretu nr 65 upoważniono organy wykonawcze do ustanawiania ograniczeń wymaganych w związku z przeciwdziałaniem wirusowi SARS-CoV-2 ${ }^{20}$. Zakres dotychczasowych daleko idących ograniczeń w sferze praw i wolności konstytucyjnych sprawia, że stan epidemii określany jest nawet jako „sui

20 Canestrini 2020, 117. 
generis pozakonstytucyjny stan nadzwyczajny"21. Niektórzy odwołują się natomiast do kategorii hybrydowego stanu nadzwyczajnego, co oznacza, że ,zaistnienie materialnych przesłanek stanu nadzwyczajnego aktualizuje określone nakazy i zakazy konstytucyjne niezależnie od braku ogłoszenia takiego stanu zgodnie z dyspozycją art. 228 ust. 2 Konstytucji”’22.

Prawodawca zwykły kształtując porządek prawny na podstawie ustawy o zapobieganiu oraz zwalczaniu zakażeń i chorób zakaźnych u ludzi dysponuje sporą swobodą ustawodawczą, która wynika z ogólnych granic wyznaczonych przez Konstytucję. Oczywiście nie oznacza to, że w zakresie regulacji praw człowieka w tych stanach funkcjonowania państwa nie wiążą go żadne ograniczenia. Przepisy wydawane na podstawie ustawy muszą spełniać konstytucyjny standard w zakresie kształtowania statusu prawnego jednostki. Przede wszystkim każdy akt normatywny dotyczący limitacji praw i wolności konstytucyjnych podlega ocenie z punktu widzenia zasad odnoszących się do dopuszczalności ograniczeń, które określono w art. 31 ust. 3 oraz w art. 53 ust. 5 Konstytucji RP. Ograniczenie wolności uzewnętrzniania religii - zgodnie z tym ostatnim przepisem - może zostać wprowadzone jedynie w akcie prawnym rangi ustawy (wymóg formalnoprawny) w celu ochrony jednej z wartości konstytucyjnych (wymóg materialnoprawny). Szczególnie istotny jest przy tym pozytywny wynik testu proporcjonalności w ocenie regulacji ograniczeń wolności z art. 53 Konstytucji RP.

\section{PRZESŁANKI WPROWADZENIA STANU EPIDEMII ORAZ STANU KLĘSKI ŻYWIOŁOWEJ}

Wybór reżimu prawnego dla podejmowania działań prawnych $\mathrm{w}$ celu przeciwdziałania rozprzestrzenianiu się wirusa SARS-CoV-2 należał do odpowiednich organów władzy publicznej. Zdaniem wielu komentatorów życia publicznego już wiosną 2020 r. należało wprowadzić stan klęski żywiołowej. Wraz z coraz dalej idącymi restrykcjami w sferze praw i wolności konstytucyjnych coraz częściej wyrażano pogląd, iż w Polsce de facto

21 Paśnik 2020, 69-85.

22 Kardas 2020, 6 i n.; Tuleja 2020, 15. 
mamy do czynienia ze stanem klęski żywiołowej (przesłanki jego wprowadzenia zostały spełnione), chociaż bez potwierdzenia tego faktu odpowiednim aktem normatywnym ${ }^{23}$. Nie wdając się w tym miejscu w kwestię oceny decyzji podjętych przez rząd warto jednak rozważyć, czy polski ustawodawca w sposób precyzyjny rozróżnia i wyznacza zakresy przedmiotowe tych dwóch instytucji prawnych, jakimi są ,stan epidemii” oraz „stan klęski żywiołowej”. Oba stany mają na celu przeciwdziałanie rozprzestrzenianiu się chorób zakaźnych i ich skutków. Kluczowa pozostaje ocena, czy na poziomie prawa stanowionego w sposób klarowny i precyzyjny rozróżniono przesłanki warunkujące ich ogłoszenie. Domniemanie racjonalności prawodawcy pozwala przyjąć, że w systemie prawnym nie występują zbędne instytucje prawne. Pomiędzy analizowanymi stanami powinny więc występować odpowiednie różnice normatywne.

Punktem wyjścia dalszych rozważań będzie przedstawienie i ocena przyjętych definicji ustawowych. W pierwszej kolejności przybliżmy znaczenie normatywne instytucji stanu zagrożenia epidemicznego oraz stanu epidemii z obowiązujących regulacji ustawowych. Kluczowe pozostaje przy tym przedstawienie znaczenia słowa „epidemia”. Jest to wyrażenie języka prawnego. W art. 2 pkt 9 u.z.c.z. przyjęto, że „epidemia” to „wystąpienie na danym obszarze zakażeń lub zachorowań na chorobę zakaźną w liczbie wyraźnie większej niż we wcześniejszym okresie albo wystąpienie zakażeń lub chorób zakaźnych dotychczas niewystępujących”. Przepisy nie precyzują, kiedy mamy do czynienia z „wyraźnie większą” liczbą zakażeń lub zachorowań na chorobę zakaźną. Nie ulega wątpliwości, iż wzrost omawianej liczby musi być znaczący względem wcześniejszego okresu. Problemów nie powinno zaś nastręczać ustalenie faktu wystąpienia nowej choroby zakaźnej lub zakażeń. Oceniając sytuację faktyczną organy państwowe powinny uwzględnić stanowisko ekspertów z zakresu epidemiologii.

Z kolei zgodnie z art. 2 pkt 22 u.z.c.z. przez „stan epidemii” rozumie się „sytuację prawną wprowadzoną na danym obszarze w związku

23 M. Kolaszczyński, 16 lipca 2020 r., Instytucja stanów nadzwyczajnych w obliczu pandemii koronawirusa SARS-CoV-2, s. 1-7, https://zbn.inp.uj.edu.pl/documents/92718966/145679069/AnalizaCOVID-1-Kolaszy\%C5\%84ski-1/c776e158-22f04a5e-a067-3d7dcb3d96a3 [dostęp: 03.09.2021]. 
z wystąpieniem epidemii $\mathrm{w}$ celu podjęcia określonych w ustawie działań przeciwepidemicznych i zapobiegawczych dla zminimalizowania skutków epidemii”. Stan epidemii określony więc został przede wszystkim jako stan prawny, wprowadzony w związku z zaistniałą epidemią. Organ uprawniony do wprowadzenia stanu zagrożenia epidemicznego oraz stanu epidemii został wskazany w art. 46 ust. 2 u.z.c.z. Stanowi się tam: „Jeżeli zagrożenie epidemiczne lub epidemia występuje na obszarze więcej niż jednego województwa, stan zagrożenia epidemicznego lub stan epidemii ogłasza i odwołuje, w drodze rozporządzenia, minister właściwy do spraw zdrowia w porozumieniu $\mathrm{z}$ ministrem właściwym do spraw administracji publicznej, na wniosek Głównego Inspektora Sanitarnego”. „Stan epidemii” jest więc stanem prawnym, który wprowadza się w związku z występującą epidemią, rozumianą na gruncie ustawy jako sytuacja faktyczna ${ }^{24}$.

Rezultat wykładni językowej przytoczonych wyżej przepisów prowadzi do wniosku, że wystąpienie przesłanek z art. 46 ust. 2 u.z.c.z. skutkuje obowiązkiem wprowadzenia stanu epidemii. Świadczy o tym imperatywne brzmienie przepisu prawnego - organ „ogłasza i odwołuje”, bez użycia operatora „może”. Jednakże wykorzystanie zwrotów niedookreślonych, takich jak „wyraźnie większa” liczba zakażeń i zachorowań sprawia, że de facto będziemy mieć do czynienia z dużym zakresem swobody organu podejmującego decyzję o wprowadzeniu stanu zagrożenia epidemicznego lub stanu epidemii. Należy jednak podkreślić, że w przypadku dokonania rzetelnej oceny i analizy sytuacji faktycznej organ powinien wprowadzić stan zagrożenia epidemicznego lub stan epidemii, jeżeli stwierdzi zaistnienie przesłanek ustawowych.

Powyższe ustalenia dotyczące stanu zagrożenia epidemicznego oraz stanu epidemii należy zestawić $\mathrm{z}$ treścią regulacji prawnej $\mathrm{z}$ ustawy z dnia 18 kwietnia 2002 r. o stanie klęski żywiołowej. Punktem wyjścia powinien być jednak art. 232 Konstytucji RP. Stanowi on, że w celu zapobieżenia skutkom katastrof naturalnych lub awarii technicznych noszących znamiona klęski żywiołowej oraz w celu ich usunięcia Rada Ministrów może wprowadzić na czas oznaczony, nie dłuższy niż 30 dni, stan klęski żywiołowej na części albo na całym terytorium państwa. Przedłużenie tego stanu może nastąpić za zgodą Sejmu.

24 Bosek 2021b, 57. 
Warto wspomnieć, że u podstaw decyzji o konstytucjonalizacji stanu klęski żywiołowej stała potrzeba ograniczenia zakresu stosowania stanu wyjątkowego, poprzez wyłączenie z niego przesłanek wprowadzenia tego stanu ze względu na zdarzenia powodowane przez awarie techniczne lub katastrofy naturalne. Stworzono więc dodatkową kategorię - stan klęski żywiołowej. Nie dokonano jednak przy tym precyzyjnego określenia ustawowych przesłanek wprowadzenia stanu klęski żywiołowej ${ }^{25}$. Warto wspomnieć, że uporządkowanie instytucji prawnych mogło polegać po prostu na zawężeniu przesłanek uzasadniających ogłoszenie stanu wyjątkowego. Dla przykładu można wskazać, że wąskie ujęcie takich przesłanek przyjęto w art. 91 niemieckiej Ustawy zasadniczej ${ }^{26}$.

Zgodnie z art. 3 ust. 1 pkt 1 u.k.ż. przez klęskę żywiołową rozumie się natomiast „katastrofę naturalną lub awarię techniczną, których skutki zagrażają życiu lub zdrowiu dużej liczby osób, mieniu w wielkich rozmiarach albo środowisku na znacznych obszarach, a pomoc i ochrona mogą być skutecznie podjęte tylko przy zastosowaniu nadzwyczajnych środków, we współdziałaniu różnych organów i instytucji oraz specjalistycznych służb i formacji działających pod jednolitym kierownictwem”. Pojęcie klęski żywiołowej jest więc zakresowo szerokie i obejmuje różne kategorie zdarzeń faktycznych ${ }^{27}$. Z punktu widzenia tytułowych rozważań kluczowe będzie wyjaśnienie pojęcia katastrofy naturalnej.

W art. 3 ust. 1 pkt 2 u.k.ż. postanowiono z kolei, że przez „katastrofę naturalną" należy rozumieć zdarzenie związane z działaniem sił natury, w szczególności wyładowania atmosferyczne, wstrząsy sejsmiczne, silne wiatry, intensywne opady atmosferyczne, długotrwałe występowanie ekstremalnych temperatur, osuwiska ziemi, pożary, susze, powodzie, zjawiska lodowe na rzekach i morzu oraz jeziorach i zbiornikach wodnych, masowe występowanie szkodników, chorób roślin lub zwierząt albo chorób zakaźnych ludzi albo też działanie innego żywiołu”.

Z przepisów ustawy o stanie klęski żywiołowej jednoznacznie wynika, że wprowadzenie tego stanu - w odróżnieniu od stanu epidemii - jest

25 Brzeziński 2007, 212-219.

26 Zob. Ustawa zasadnicza Republiki Federalnej Niemiec z 23 maja 1949 r., http://libr. sejm.gov.pl/tek01/txt/konst/niemcy.html [dostęp: 16.08.2021].

27 Ruczkowski 2002. 
fakultatywne. W art. 4 ust. 1 u.k.ż. przyjęto bowiem, że „stan klęski żywiołowej może być wprowadzony na obszarze, na którym wystąpiła klęska żywiołowa, a także na obszarze, na którym wystąpiły lub mogą wystąpić skutki tej klęski”. Nie ulega wątpliwości, że daleko idące konsekwencje prawne wprowadzenia stanu klęski żywiołowej wymagają zapewnienia odpowiedniej swobody decyzyjnej organów władzy publicznej w sprawie ogłoszenia tego stanu nadzwyczajnego. Jak zresztą wspomniano już wcześniej, samo użycie zwrotów niedookreślonych prowadzi de facto do uznania pewnego zakresu swobody oceny, nawet jeżeli przepis prawny sformułowany jest kategorycznie.

Z omówionych wyżej definicji wynika, że stan klęski żywiołowej może zostać wprowadzony na obszarze części lub całego kraju m.in. ze względu na wystąpienie właśnie choroby zakaźnej. Z całokształtu regulacji ustawy odnoszącej się do tego stanu można wyprowadzić wniosek, że wprowadzenie stanu klęski żywiołowej jest możliwe, jeżeli występująca choroba zakaźna ludzi przyjmie znamiona „klęski żywiołowej”. Definicje z art. 3 ust. 1 pkt 1 i 2 u.k.ż. wyróżnia jednak bardzo wysoki poziom ogólności. Jest on w szczególności znacznie wyższy od tego, który można dostrzec w przepisach ustawy o zapobieganiu oraz zwalczaniu zakażeń i chorób zakaźnych u ludzi. Definicje te zawierają liczne zwroty niedookreślone, w których mowa jest o zagrożeniu dla „dużej liczby osób”, „mieniu w wielkich rozmiarach" albo wspomina się o ,środowisku na znacznych obszarach". Powyższe wyrażenia nie zostały zdefiniowane w słowniczku ustawowym. Nie można jednak czynić z tego zarzutu, gdyż prawo stanowione musi się cechować pewnym poziomem elastyczności, który ułatwi stosowanie przepisów do zróżnicowanych sytuacji, które mogą wystąpić w rzeczywistości. Rolą organów stosujących omawiane tu przepisy będzie więc staranne zbadanie, czy w zaistniałych okolicznościach faktycznych zachodzą przesłanki wprowadzenia stanu klęski żywiołowej ze względu na występowanie choroby zakaźnej.

W praktyce mogą wystąpić trudności z oceną sytuacji faktycznej i interpretacją ogólnych przepisów prawnych dotyczących wprowadzenia stanu zagrożenia epidemicznego, stanu epidemii czy stanu klęski żywiołowej. Konieczne jest przeprowadzenie oceny skali zagrożenia, a także odpowiedź na pytanie o możliwość zaradzenia sytuacji środkami 
zwyczajnymi ${ }^{28}$. Szczególnie ważne będzie podanie opinii publicznej dokładnych motywów decyzji o wprowadzeniu wybranego reżimu prawnego. Za istotną trzeba też uznać troskę o to, aby wydawane szczegółowe regulacje normatywne mieściły się $\mathrm{w}$ ramach wybranej instytucji prawnej. Dotyczy to również wprowadzanych ograniczeń w sferze praw człowieka ${ }^{29}$.

Wydaje się, że różnica pomiędzy stanem epidemii a stanem klęski żywiołowej wprowadzanym z uwagi na chorobę zakaźną występuje przede wszystkim na płaszczyźnie przebiegu epidemii i skali jej skutków. Powyższe instytucje prawne ustanowione zostały do przeciwdziałania rozprzestrzenianiu się chorób zakaźnych i ich skutkom. Stan epidemii oraz stan zagrożenia epidemicznego łączą się głównie z podejmowaniem działań bieżących określonych w ustawie, które mają zahamować rozprzestrzenianie się choroby zakaźnej. Powyższe cele są również ważne z punktu widzenia kategorii stanu klęski żywiołowej, lecz w odniesieniu do tej instytucji prawnej akcent położony został przede wszystkim na przeciwdziałanie skutkom i łagodzenie zaistniałych już następstw epidemii. Można wyobrazić sobie sytuację, gdy po wprowadzeniu stanu epidemii ogłaszany jest stan klęski żywiołowej. Uprzednie ogłoszenie stanu epidemii nie może być jednak oczywiście traktowane jako wymóg prawny wprowadzenia stanu klęski żywiołowej. Trudno także podzielić zasadność postulatu wprowadzenia stanu klęski żywiołowej po 7 dniach od ogłoszenia stanu epidemii ${ }^{30}$. Rolą decydentów politycznych będzie ustalenie, która instytucja prawna może okazać się bardziej adekwatna do potrzeb sytuacji i możliwości osiągnięcia zakładanych celów. Wydaje się, że dla oceny zasadności wprowadzenia stanu klęski żywiołowej kluczowe będzie przede wszystkim przeprowadzenie pogłębionych analiz w zakresie

28 Kurzępa 2021, 18.

29 P. Tuleja, 10 kwietnia 2020 r., Ustawa o stanie klęski żywiołowej czy ustawa o zapobieganiu oraz zwalczaniu zakażeń i chorób zakaźnych u ludzi (polemika), „Monitor Konstytucyjny. Konstytucja, Państwo, Prawo", https://monitorkonstytucyjny.eu/archiwa/13404 [dostęp: 03.09.2021].

30 E. Gierach, 17 sierpnia 2020 r., Opinia dotyczaca petycji $n r$ BKSP-145-IX-108/20 w sprawie zmiany ustawy o stanie klęski żywiołowej, http://orka.sejm.gov.pl/petycje.nsf/nazwa/IX-108/\$file/IX-108.pdf [dostęp: 03.09.2021]. 
zaistnienia przesłanki określonej jako ,skutki zagrożenia życia lub zdrowia dużej liczby osób".

\section{REALIZACJA WOLNOŚCI SUMIENIA I RELIGII}

W STANIE ZAGROŻENIA EPIDEMICZNEGO ORAZ W STANIE EPIDEMII A INNE PRAWA I WOLNOŚCI KONSTYTUCYJNE

Ustawa o zapobieganiu oraz zwalczaniu zakażeń i chorób zakaźnych u ludzi dopuszcza w szerokim zakresie ograniczenie praw i wolności konstytucyjnych. Art. 46 ust. 4 tej ustawy (a także art. 46b) dopuszcza wprowadzanie ograniczeń praw człowieka w drodze rozporządzenia, co budzi poważne wątpliwości co do zgodności z Konstytucją RP. Należy bowiem stwierdzić, że art. 31 ust. 3 polskiej Ustawy zasadniczej, podobnie jak jej art. 53 ust. 5, wyraźnie stanowią, że ograniczenie praw i wolności konstytucyjnych, w tym wolności uzewnętrzniania religii, może zostać dokonane tylko z wykorzystaniem aktu prawnego rangi ustawy. Oznacza to, że ewentualne ograniczenia w zakresie korzystania z wolności z art. 53 Konstytucji $\mathrm{RP}$ również w stanie epidemii powinny być ustanawiane w drodze ustawowej. Akt prawny tej rangi posiada bowiem odpowiednią legitymację, co jest szczególnie istotne z punktu widzenia społecznej aprobaty dla wprowadzanych ograniczeń praw człowieka ${ }^{31}$. Inaczej jest w przypadku rozporządzenia, które wydawane jest przez organ władzy wykonawczej. Władze wykonawcze na gruncie regulacji u.z.c.z. nie otrzymały kompetencji do możliwości ustanawiania ograniczeń wolności kultu religijnego ${ }^{32}$.

$\mathrm{W}$ art. 46 u.z.c.z. ustawodawca posłużył się metodą enumeracji pozytywnej, wskazując prawa (wolności), które mogą zostać ograniczone $\mathrm{w}$ stanie epidemii. W zasadzie sa to wybrane uprawnienia $\mathrm{z}$ zakresu poszczególnych praw i wolności konstytucyjnych. Nie zdecydowano się natomiast na wymienienie praw (wolności) metodą hasłową, lecz jedynie wskazano wybrane zachowania, które mogą zostać obłożone zakazami lub ograniczeniami w stanie zagrożenia epidemicznego lub stanie epidemii. Taka metoda legislacyjna pozwala przyjąć, że ustawodawca dopuszcza

31 Wojtyczek 1999, 107.

32 Stanisz 2021, 154. 
ograniczenie jedynie określonych form realizacji poszczególnych praw lub wolności. Nie wyraża natomiast zgody na zawieszenie wszystkich uprawnień z zakresu danego prawa lub wolności konstytucyjnej. Dla porównania warto wskazać, że właśnie taką zgodę wyraził ustrojodawca w art. 233 Konstytucji RP. Hasłowo wskazane tu zostały te prawa człowieka, które mogą zostać zawieszone w stanach nadzwyczajnych. Użyto przy tym metody enumeracji pozytywnej (stan klęski żywiołowej) oraz metody enumeracji negatywnej (stan wojenny i stan wyjątkowy) ${ }^{33}$. Ustawodawca zwykły nie ma więc uprawnień do wprowadzenia całkowitego zawieszenia wolności sumienia i religii ani też ograniczenia innych praw i wolności człowieka i obywatela z naruszeniem ich istoty. Granice dopuszczalnej ingerencji w sferę praw człowieka w stanach wprowadzanych na podstawie przepisów ustawy o zapobieganiu oraz zwalczaniu zakażeń i chorób zakaźnych u ludzi wyznacza art. 31 ust. 3 Konstytucji RP.

Omawiane regulacje ustawowe nie zezwalają wprost na ograniczenie wolności sumienia i religii w stanie epidemii, gdyż nie przewidziano regulacji prawnych w tej materii ${ }^{34}$. Stan ten należy ocenić pozytywnie. Ograniczenia przewidziane w ustawie o zapobieganiu oraz zwalczaniu zakażeń i chorób zakaźnych powinny zawsze pozostawać w związku z koniecznością przeciwdziałania rozprzestrzenianiu się takiej choroby. Należy przy tym mieć na uwadze, że wolność sumienia i religii obejmuje szeroki zakres uprawnień, w tym także takie, których realizacja nie łączy się w żaden sposób ze zjawiskiem rozprzestrzeniania się wirusa. Przegląd zawartości normatywnej art. 46 u.z.c.z. może a prima vista prowadzić do wniosku, że uprawnienia wymienione $\mathrm{w}$ tym przepisie są irrelewantne $\mathrm{z}$ punktu widzenia realizacji wolności sumienia i religii. Jednakże z uwagi na złożoną naturę wolności z art. 53 Konstytucji RP, ograniczenia w zakresie korzystania z innych praw i wolności mogą utrudnić realizację uprawnień szczegółowych z zakresu wolności sumienia i religii. W dalszej części tekstu przedstawiono wpływ ograniczeń poszczególnych praw i wolności konstytucyjnych na zakres realizacji wolności sumienia i religii. Warto przy tym zaznaczyć obszary, w których dochodziło wprost do ograniczeń uprawnień z zakresu wolności z art. 53 Konstytucji RP w aktach prawnych

33 Działocha 2005, 2.

34 Trociuk 2021. 
wydawanych w Polsce w okresie pandemii. Należy przy tym poczynić uwagę prawnoporównawczą, iż nie we wszystkich państwach zaakceptowano $\mathrm{w}$ orzecznictwie zakres epidemicznych ingerencji $\mathrm{w}$ sferę praw człowieka, w tym wolności sumienia i religii. Jako przykład warto podać orzeczenie francuskiej Rady Stanu (Conseil d'Etat), w którym zakwestionowano legalność tzw. lockdownu ${ }^{35}$ i ograniczenia w zakresie prawa do zgromadzeń religijnych w miejscach kultu ${ }^{36}$.

Art. 46 ust. 4 pkt 1 u.z.c.z. dopuszcza „,czasowe ograniczenie określonego sposobu przemieszczania się". Prima facie przepis ten dotyczy tylko wolności przemieszczania się. Jednakże limitacja wolności z art. 52 Konstytucji RP istotnie może ograniczyć również realizację wielu uprawnień szczegółowych z zakresu wolności sumienia i religii. Warto wskazać przykład, który zilustruje problem zbiegu praw i wolności konstytucyjnych. Udział człowieka w pieszej pielgrzymce religijnej stanowi z jednej strony przejaw realizacji wolności przemieszczania się, będąc też jednak $\mathrm{z}$ drugiej strony aktem uzewnętrzniania religii ${ }^{37}$. Tak samo jest w przypad$\mathrm{ku}$, gdy dana osoba, w celu uczestniczenia w zbiorowych praktykach religijnych, pragnie dotrzeć do świątyni, co może być utrudnione lub nawet niemożliwe ze względu na ograniczenia wolności przemieszczania się czy też nakaz przebywania w określonym miejscu. W tym drugim przypadku nie mamy do czynienia ze zbiegiem praw i wolności konstytucyjnych, lecz z sytuacją, gdy zagwarantowanie wolności z art. 52 Konstytucji RP umożliwia realizację jednego $\mathrm{z}$ uprawnień $\mathrm{z}$ zakresu wolności sumienia i religii. Konieczne jest wówczas łączne zagwarantowanie obu praw wolnościowych. Zawieszenie wolności przemieszczania się wiąże się bowiem $\mathrm{z}$ uniemożliwieniem skorzystania przez jednostkę z wolności z art. 53 polskiej Ustawy zasadniczej. Nie ulega wątpliwości, że w takiej sytuacji może dojść do pośredniego ograniczenia wolności sumienia i religii. Rozporządzenia z marca 2020 r. przewidywały liczne restrykcje dotyczące mobilności społecznej, co niewątpliwie utrudniało realizację wolności z art. 53 Konstytucji RP. Aczkolwiek występowały także odstępstwa na rzecz ,przemieszczania się sprawowania lub uczestniczenia w sprawowaniu kultu

\footnotetext{
35 Syndicat des jeunes médecins, $\mathrm{N}^{\circ}$ 439674, 22 mars 2020.

36 Association Civitas, $\mathrm{N}^{\circ}$ 440361, 440511, 18 mai 2020.

37 Ożóg 2016, 58.
} 
religijnego, w tym czynności lub obrzędów religijnych"38, co zasadniczo nie wzbudzało kontrowersji $i^{39}$.

Art. 46 ust. 4 pkt 2 u.z.c.z. dopuszcza ,czasowe ograniczenie lub zakaz obrotu i używania określonych przedmiotów lub produktów spożywczych”. Wydaje się, że na podstawie tego przepisu prawnego nie będą wprowadzane ograniczenia w sferze wolności sumienia i religii. Potwierdza to również obecna praktyka prawodawcza w stanie epidemii. Nie przewidziano dotychczas ograniczeń, które byłyby wprowadzone na podstawie tego przepisu prawnego, mając odniesienie do działalności kościołów i innych związków wyznaniowych lub osób fizycznych korzystających z wolności sumienia i religii. Warto w tym miejscu jednak wspomnieć o postulacie jednej z posłanek, aby zakazać prawnie przyjmowania Komunii św. do $\mathrm{ust}^{40}$. Prawdopodobnie interpelantka opierała swój postulat właśnie na przesłance ustawowej z art. 46 ust. 4 pkt 2 u.z.c.z. Oczywiście konsekrowany komunikant nie jest typowym produktem spożywczym. Dla ludzi wierzących jest Ciałem Chrystusa. Prawo świeckie oczywiście nie używa tego określenia, a w sensie fizycznym jest to opłatek przeznaczony do spożycia i w tym znaczeniu mógłby zostać uznany za produkt spożywczy. Wydaje się jednak, że postulowany w interpelacji zakaz nadmiernie ingerowałby nie tylko w wolność jednostki, ale także w swobodę wypełniania funkcji religijnych przez kościoły i inne związki wyznaniowe ${ }^{41}$.

Zgodnie z art. 46 ust. 4 pkt 3 u.z.c.z. dopuszczalne w okresie epidemii jest „czasowe ograniczenie funkcjonowania określonych instytucji lub zakładów pracy". Przepis ten nie precyzuje, o jakie instytucje tu chodzi. $\mathrm{Z}$ pewnością $\mathrm{W}$ zakres regulacji wejdą budynki użyteczności publicznej (np. szkoły, podmioty lecznicze, teatry, kina, muzea, archiwa, zakłady lecznictwa uzdrowiskowego itd.). Do określenia pozostaje, czy zgodne

38 Np. $§ 5$ pkt 5 rozporządzenia Rady Ministrów z dnia 30 marca 2020 r. w sprawie ustanowienia określonych ograniczeń, nakazów i zakazów w związku z wystąpieniem stanu epidemii, Dz. U. z 2020 r., poz. 566 z późn. zm.

39 Morawski 2020, 11.

40 Interpelacja nr 12702 do ministra zdrowia w sprawie zakazu bezpośredniego kontaktu przy udzielaniu Komunii Świętej, https:/www.sejm.gov.pl/Sejm9.nsf/InterpelacjaTresc.xsp?key=BUMAU9 [dostęp: 03.09.2021].

${ }^{41}$ Inną sprawą jest to, że ten sposób przyjmowania Komunii św. rzeczywiście nie jest w pełni bezpieczny z punktu widzenia standardów ochrony sanitarnej. 
z tym przepisem będzie ograniczenie funkcjonowania kościołów i innych związków wyznaniowych. Przepisy ustawy o zapobieganiu oraz zwalczaniu zakażeń i chorób zakaźnych u ludzi w żaden sposób nie zawężają kategorii instytucji objętych omawianą regulacją. W myśl zasady lege non distinguente nec nostrum est distinguere należy więc uznać dopuszczalność wprowadzania ograniczeń działalności kościołów i innych związków wyznaniowych w oparciu o przedmiotowy przepis prawny. W literaturze występuje pogląd odmienny, zgodnie z którym przepis ten nie może stanowić podstawy „reglamentacji publicznych aktów kultu religijnego”, ponieważ akty kultu łączą się z realizacją wolności religii (art. 53 Konstytucji), a nie wolności zgromadzeń (art. 57 Konstytucji) ${ }^{42}$. Dotychczasowa praktyka prawodawcza wskazuje, że jednak na tej właśnie podstawie wprowadzane są liczne obostrzenia dotyczące działalności kościołów i innych związków wyznaniowych.

Przepis art. 46 ust. 4 pkt 3 u.z.c.z. musi być interpretowany w świetle art. 25 ust. 3 Konstytucji RP. Trudno byłoby przyjąć, że powołane unormowanie ustawowe dopuszcza ingerencję w wewnętrzne sprawy wspólnoty religijnej przez podejmowanie działań niemających związku z przeciwdziałaniem rozprzestrzenianiu się choroby zakaźnej. Należy zatem uznać, że ograniczenie funkcjonowania kościołów i innych związków wyznaniowych w oparciu o omawiany przepis prawny nie dotyczy działalności wewnętrznej wspólnoty, a więc - innymi słowy - działalności, która nie łączy się z organizacją zbiorowych praktyk religijnych. Za przykład może tu posłużyć codzienne życie osób duchownych i świeckich przebywających w domu zakonnym czy budynku parafialnym. Wprowadzając ograniczenia dotyczące działalności instytucji kościelnych trzeba bowiem przestrzegać zasady autonomii i niezależności kościołów i innych związków wyznaniowych z art. 25 ust. 3 Konstytucji RP. Przeciwdziałanie epidemii nie może być pretekstem do ingerowania w sprawy wewnętrzne wspólnot religijnych. Ustanawiane ograniczenia powinny dotyczyć zatem przede wszystkim organizacji zbiorowych, publicznych praktyk religijnych, a więc organizacji wydarzeń sakralnych z określoną liczbą uczestników. Musi bowiem chodzić o zgromadzenia, z odbywaniem których wiąże się ryzyko transmisji wirusa.

42 Maroń 2021, 39. 
Przepis art. 46 ust. 4 pkt 4 u.z.c.z. dopuszcza wprowadzenie ,zakazu organizowania widowisk i innych zgromadzeń ludności”. Dotyczy to przede wszystkim ograniczeń w zakresie realizacji uprawnień określonych w ustawie z dnia 24 lipca 2015 r. - Prawo o zgromadzeniach ${ }^{43}$. Ograniczenia wprowadzane na podstawie wskazanego wyżej przepisu mogą jednak dotyczyć również organizacji zbiorowych praktyk religijnych. Warto zwrócić uwagę, że na poziomie omawianych regulacji ustawowych nie zostały przewidziane żadne gwarancje prawne na rzecz ochrony prawa do organizowania zgromadzeń przez kościoły i inne związki wyznaniowe. Jest to zaskakujące, biorąc pod uwagę, że takie właśnie zabezpieczenie wolności sumienia i religii zostało ustanowione w art. 22 ust. 2 ustawy $\mathrm{z}$ dnia 21 czerwca 2002 r. o stanie wyjątkowym ${ }^{44}$ (przepis ten stanowi, że zakaz zgromadzeń $\mathrm{w}$ tym stanie funkcjonowania państwa nie dotyczy zgromadzeń organizowanych przez kościoły i inne związki wyznaniowe oraz organizacje religijne działające w obrębie świątyń, budynków kościelnych, w innych pomieszczeniach służących organizowaniu i publicznemu sprawowaniu kultu). Oczywiście nie ma przeszkód, aby prawodawca w wydawanych rozporządzeniach ustanowił odpowiednie gwarancje w zakresie wolności sumienia i religii w stanie zagrożenia epidemicznego lub stanie epidemii. Jednakże przy braku odpowiednich gwarancji konstytucyjnych i ustawowych jest to pozostawione wyłącznie woli prawodawcy $\mathrm{i}$ istnieje zagrożenie, że - z bardzo różnych względów - nie przewidzi on takiego wyjątku.

Ustanowienie odpowiednich zabezpieczeń dla wolności gromadzenia się w celach religijnych jest szczególnie istotne. Szereg uprawnień szczegółowych z zakresu wolności sumienia i religii materializuje się właśnie w postaci udziału w zbiorowych praktykach religijnych. Prawodawca ustanawiał już wyjątki od zakazu zgromadzeń w odniesieniu do takich zgromadzeń, o ile liczba ich uczestników wynosiła nie więcej niż 50 osób (wliczając $w$ to organizatora i osoby działające w jego imieniu). Odnoszące się do tego limity ulegały zmianie w dotychczasowym okresie trwania pandemii,

43 Ustawa z dnia 24 lipca 2015 r. - Prawo o zgromadzeniach, tekst jedn. Dz. U. z 2019 r., poz. 631 .

44 Ustawa z dnia 21 czerwca 2002 r. o stanie wyjątkowym, tekst jedn. Dz. U. z 2017 r., poz. 1928. 
a najniższy z nich wynosił jedynie 5 osób. Trzeba przy tym podkreślić, że omawiane odstępstwo od generalnego zakazu zgromadzeń miało istotne znaczenie pozytywne dla realizacji wolności sumienia i religii, w tym prawa do udziału w zbiorowych praktykach religijnych.

Jak już wskazano wyżej, ograniczenia w zakresie korzystania z wolności z art. 53 Konstytucji RP w okresie stanu zagrożenia epidemicznego oraz stanu epidemii muszą uwzględniać wymogi z art. 31 ust. 3 i art. 53 ust. 5 tej Ustawy zasadniczej. Regulacje prawne wydawane na podstawie art. 46 ust. 2 i 4 u.z.c.z. podlegają kontroli konstytucyjności prawa. Ogłoszenie powyższych stanów nie uprawnia do ustanawiania ograniczeń uzewnętrzniania religii w zakresie szerszym niż te, które odnoszą się do warunków zwyczajnego funkcjonowania państwa. Innymi słowy, jeżeli sytuacja faktyczna związana z występowaniem choroby zakaźnej wymaga sięgnięcia po środki wyjątkowe, to wówczas powinien zostać ogłoszony stan klęski żywiołowej na obszarze części lub całego kraju. Warto przy tym zwrócić uwagę na szczególny kontekst art. 46 u.z.c.z., jaki tworzą przepisy rozdziału XI Konstytucji RP. Powinny one bowiem stanowić punkt odniesienia dla oceny konstytucyjności i legalności ograniczeń wprowadzanych w stanie zagrożenia epidemicznego i w stanie epidemii ${ }^{45}$.

Regulacje ustawowe, podobnie jak i unormowania aktów wykonawczych, muszą być zgodne z art. 31 ust. 3 i art. 53 ust. 5 Konstytucji RP. Pod wieloma względami akty wykonawcze wydawane w Polsce w okresie pandemii budzą poważne wątpliwości konstytucyjne ${ }^{46}$. Podstawowy zarzut dotyczy braku odpowiedniej podstawy prawnej do wprowadzenia ograniczeń praw człowieka, a także proporcjonalności wprowadzanych ograniczeń. Należy w tym miejscu wskazać na wadliwość polegającą na dopuszczeniu w art. 46 u.z.c.z., aby limitacja pewnych praw i wolności konstytucyjnych dokonywała się $\mathrm{w}$ drodze rozporządzenia. Prawa człowieka mogą być ograniczane wyłącznie w drodze ustawy. W obecnej sytuacji proponuje się ewentualne dodanie delegacji ustawowej upoważniającej Radę Ministrów do ustanowienia ograniczeń w sferze wolności z art. 53 Konstytucji RP,

45 Bosek 2021c, 748.

46 Dyda, Olszówka 2020, 441-469; powołany wyżej artykuł: J. Kwaśniewski, T. Zych, M. Olszówka, K. Dyda, 16 kwietnia 2020 r., Analiza wprowadzonych. 
a w dalszej perspektywie można rozważyć uchwalenie ustawy, w której dopuszczona zostałaby ingerencja w wolność sumienia i religii ${ }^{47}$.

Z punktu widzenia ochrony wolności sumienia i religii należy wskazać na brak dostatecznych gwarancji prawnych tej wolności w stanie epidemii. W tym też uwidacznia się brak spójności aksjologicznej systemu prawa polskiego. Wysoka ranga wolności sumienia i religii określona w Konstytucji nie koresponduje $\mathrm{z}$ poziomem ochrony tej wolności $\mathrm{w}$ prawodawstwie stanu epidemii. Za niewystarczający należy uznać brak wskazania wolności sumienia i religii w katalogu uprawnień, które mogą być ograniczone na podstawie ustawy o zapobieganiu oraz zwalczaniu zakażeń i chorób zakaźnych u ludzi. Poszukując w obecnym stanie prawnym mechanizmu ochrony tej wolności należy wskazać na instytucję kontroli konstytucyjności prawa. Brak proporcjonalności ustanawianych ograniczeń innych praw i wolności będzie refleksem wpływał na możliwości realizacji wolności sumienia i religii. Drugim wariantem rozwiązania tej sytuacji jest próba podjęcia odpowiednich zmian systemowych w prawie polskim. Wydaje się, iż takie działania są konieczne. Warto rozważyć ustanowienie odpowiednich zabezpieczeń prawnych dla realizacji poszczególnych uprawnień szczegółowych z zakresu wolności sumienia i religii w stanie zagrożenia epidemicznego lub w stanie epidemii. Przepisy mogłyby przyjąć postać wyjątków od dopuszczalności ograniczeń poszczególnych praw (wolności) z uwagi na ochronę wolności z art. 53 Konstytucji RP. Może to dotyczyć w szczególności zgromadzeń religijnych czy też przemieszczania się w celu realizacji praktyk religijnych (oczywiście przy zachowaniu zasad bezpieczeństwa sanitarnego). Odpowiednie regulacje prawne mogłyby zostać zamieszczone w ustawie o zapobieganiu oraz zwalczaniu zakażeń i chorób zakaźnych u ludzi, Prawie o zgromadzeniach, ustawie z dnia 17 maja 1989 r. o gwarancjach wolności sumienia i wyznania ${ }^{48}$ czy ustawach w sposób indywidualny określających status prawny poszczególnych kościołów i innych związków wyznaniowych. Należy jednak podkreślić, że wszelkie zmiany legislacyjne powinny zostać przeprowadzone w taki sposób, aby nie powstało wrażenie faworyzowania osób

47 Bielecki 2021, 56-57.

48 Ustawa z dnia 17 maja 1989 r. o gwarancjach wolności sumienia i wyznania, tekst jedn. Dz. U. z 2017 r., poz. 1153. 
o światopoglądzie religijnym. Z pewnością wymagałoby to przeprowadzenia odpowiednich konsultacji społecznych i eksperckich.

Poszukując gwarancji prawnych wolności sumienia i religii w stanie zagrożenia epidemicznego i stanie epidemii należy wspomnieć również o normie prawnej z art. 53 ust. 2 zd. 2 in fine Konstytucji RP. Wyraźnie formułuje się tu prawo każdego do pomocy religijnej, tam gdzie się znajduje. Nie ulega wątpliwości, że przepis ten może mieć szczególne znaczenie w przypadku osób, które zostały przymusowo umieszczone w miejscu odosobnienia z uwagi na chorobę zakaźną. Może to dotyczyć w szczególności pobytu w izolatorium czy podmiocie leczniczym. Prawo do opieki duszpasterskiej ma charakter względny i może zostać ograniczone w stanie zagrożenia epidemicznego, w stanie epidemii i w stanie klęski żywiołowej, jeżeli zostaną spełnione przesłanki z art. 31 ust. 3 i art. 53 ust. 5 Konstytucji RP. Sformułowane powyżej uwagi w pełnym zakresie odnoszą się także do statusu prawno-wyznaniowego jednostki w stanie klęski żywiołowej.

\section{REALIZACJA WOLNOŚCI SUMIENIA I RELIGII W STANIE KLĘSKI ŻYWIOŁOWEJ A INNE PRAWA I WOLNOŚCI KONSTYTUCYJNE}

Jak już wspomniano, zasadnicza różnica w regulacji prawnej stanu epidemii i stanu klęski żywiołowej wynika z uznania tego drugiego za stan nadzwyczajny ujęty w Konstytucji RP. W jej art. 233 ust. 3 ustrojodawca enumeratywnie wskazał prawa i wolności człowieka i obywatela, które mogą zostać zawieszone w czasie trwania stanu klęski żywiołowej. Zastosowanie w tym przypadku klauzuli pozytywnej zasadniczo bywa przyjmowane z aprobatą, gdyż podmioty prawa mają dzięki temu pewność w ustaleniu praw (wolności), które mogą podlegać ograniczeniom. Jednakże w literaturze przedmiotu wyrażane są także pewne wątpliwości wobec tej techniki legislacyjnej ${ }^{49}$.

Wolność sumienia i religii nie została wymieniona w katalogu $\mathrm{z}$ art. 233 ust. 3 Konstytucji RP. Oznacza to, iż w trakcie trwania stanu klęski żywiołowej nie jest możliwe ograniczenie tej wolności ponad standard wynikający z art. 31 ust. 3 i art. 53 ust. 5 tej Ustawy zasadniczej. Z punktu widzenia

49 Prokop 2005, 136. 
reguł ograniczania praw i wolności konstytucyjnych w stanie klęski żywiołowej należy wskazać na szczególne znaczenie wymogu ustawowej podstawy dokonania ingerencji w sferę praw człowieka (co wynika $\mathrm{z}$ art. 228 ust. 3 w związku z art. 233 Konstytucji RP) $)^{50}$.

W kontekście problematyki realizacji wolności sumienia i religii w stanie klęski żywiołowej istotne znaczenie ma również możliwość zawieszenia prawa do wolności przemieszczania się i wyboru miejsca pobytu z identycznych powodów, które zostały już podniesione w odniesieniu do stanu epidemii. Powyższe ograniczenia mogą być wprowadzone na podstawie art. 21 ust. 1 pkt 12 i 15 u.k.ż. Wskazuje to na złożoność realizacji ustrojowego założenia niederogowalności wolności sumienia i religii w stanie klęski żywiołowej. Pod dyskusję można poddać rozważenie wprowadzenia ewentualnych wyjątków na rzecz ochrony wolności sumienia i religii.

Z innych przepisów prawnych, które mogą stanowić podstawę ograniczeń wolności sumienia i religii w stanie klęski żywiołowej, należy wskazać art. 21 ust. 1 pkt 5 u.k.ż. Przewiduje się w nim nałożenie obowiązku poddania się badaniom lekarskim, leczeniu, szczepieniom ochronnym oraz stosowaniu innych środków profilaktycznych i zabiegów, niezbędnych do zwalczania chorób zakaźnych oraz skutków skażeń chemicznych i promieniotwórczych. Z kolei art. 1 ust. 1 pkt 7 u.k.ż. stanowi, że ograniczenie praw i wolności człowieka może polegać na obowiązku stosowania środków ochrony roślin lub innych środków zapobiegawczych niezbędnych do zwalczania organizmów szkodliwych dla ludzi, zwierząt lub roślin. Warto przy tym nadmienić, że obowiązek poddania się szczepieniom ochronnym może wynikać także z art. 17 ust. 10 pkt 2 u.z.c.z. Nie ulega wątpliwości, że powyższe regulacje prawne mogą się przekładać na ograniczenie wolności osobistej człowieka z art. 41 ust. 1 zd. 1 Ustawy zasadniczej, co sprawia, że część ograniczeń wykracza poza zakres ograniczeń dopuszczony przez Konstytucję ${ }^{51}$.

Z punktu widzenia problematyki wolności sumienia i religii szczególnie istotne znaczenie może mieć wprowadzenie obowiązku poddania się szczepieniom ochronnym przeciwko chorobie zakaźnej. Dotyczy to także

50 Kazimierczuk 2005, 91.

51 Ruczkowski 2002, LEX/el. 
działań mających na celu przeciwdziałanie COVID-19. Obowiązek poddania się takim szczepieniom może budzić kontrowersje, gdyż stanowi ograniczenie wolności osobistej oraz prawa do samostanowienia. Przyjmując, że przekonania człowieka $\mathrm{w}$ tej kwestii stanowią element wyznawanego światopoglądu, to w przypadku ustanowienia szczepień obligatoryjnych można byłoby rozważać kwestię naruszenia wolności sumienia (prawa do samostanowienia), a w pewnych przypadkach - jak się wydaje - także wolności religii. Jednakże $\mathrm{w}$ ocenie piszącego ograniczenie wolności $\mathrm{z}$ art. 53 Konstytucji RP poprzez ustanowienie prawnego obowiązku poddania się szczepieniu przeciwko chorobie zakaźnej może spełniać wymóg proporcjonalności pod pewnymi warunkami i znajduje swoje uzasadnienie w przesłance ochrony zdrowia publicznego, która wyraźnie ujęta jest zarówno w art. 31 ust. 3, jak i art. 53 ust. 5 Konstytucji RP. W literaturze wskazuje się, że szczepienia służą ochronie jednostki i społeczeństwa ${ }^{52}$.

Kwestią sporną będzie ustalenie, czy w takich przypadkach możliwe jest powołanie się przez pacjenta na prawo do sprzeciwu sumienia (jeśli odmowa zgody na szczepienie posiada motywację konfesyjną). Wydaje się, że na tak postawione pytanie należy odpowiedzieć negatywnie ze względu na treść art. 21 ust. 1 pkt 5 u.k.ż. Pogląd ten opiera się na założeniu, że do realizacji klauzuli sumienia konieczne jest istnienie odrębnego przepisu prawnego rangi ustawowej ${ }^{53}$. W literaturze prezentowany jest też pogląd odmienny, który zakłada, że prawo do powołania się na sprzeciw sumienia wynika już z samej zawartości normatywnej art. 53 ust. 1 Konstytucji RP w związku z jej art. 8 ust. 2 i żaden szczególny przepis ustawy regulującej daną kategorię stosunków społecznych nie jest już potrzebny ${ }^{54}$. Bez względu na to, które z zaprezentowanych stanowisk jest trafne, nie ulega wątpliwości, że obecna treść ustawy o stanie klęski żywiołowej nie przewiduje gwarancji prawnych na rzecz możliwości odmowy poddania się szczepieniom ochronnym ze względu na wyznawane przekonania. Można argumentować, że gdyby ustawodawca chciał taką możliwość dopuścić, to w którejś z odnoszących się do tego ustaw uwzględniłby przepis

52 Pałka 2018, 603.

53 Tak np. sędzia S. Biernat w zdaniu odrębnym do wyroku Trybunału Konstytucyjnego z dnia 7 października 2015 r., K 12/14, LEX nr 1809416.

54 Tak np. Zoll 2014, 99-103. 
statuujący klauzulę sumienia, tak jak to uczynił w niektórych innych aktach normatywnych. Taki sam wniosek należy wyprowadzić w przypadku ewentualnego wprowadzenia wymogu zaszczepienia dziecka przeciwko COVID-19. W pewnych przypadkach może dojść wówczas do naruszenia prawa rodziców do wychowania dziecka zgodnie z własnymi przekonaniami (art. 48 Konstytucji RP), lecz będzie to dopuszczalne w razie umocowania tego obowiązku w ustawie. Przemawia za tym przesłanka ochrony zdrowia publicznego. Warto zwrócić uwagę, że tak samo przyjmuje się w przypadku braku zgody na zaszczepienie dziecka w odniesieniu do szczepień obowiązkowych w zwyczajnych warunkach funkcjonowania państwa. W orzecznictwie sądowoadministracyjnym sformułowano tezę, że nie można powoływać się na klauzulę sumienia w przypadku odmowy rodziców na zaszczepienie dziecka ${ }^{55}$.

Przepis art. 21 ust. 2 pkt 2 u.k.ż. dopuszcza nałożenie ,obowiązku pracy w niedziele, święta i dni wolne od pracy wynikające z rozkładu czasu pracy w pięciodniowym tygodniu pracy, w tym wydłużeniu okresu rozliczeniowego do dwunastu miesięcy, na zasadach określonych w Kodeksie pracy". Przepis ten ogranicza zatem prawo do wypoczynku z art. 66 ust. 2 Konstytucji RP. Prawo obchodzenia dnia świątecznego stanowi też ważne uprawnienie z zakresu wolności sumienia i religii. W nauczaniu wielu wspólnot religijnych niedziela stanowi bowiem dzień, w którym należy powstrzymać się od pracy i oddać powinnościom religijnym, np. uczestniczyć w określonych praktykach religijnych. Wydaje się, że również powyższe ograniczenie znajduje swoje uzasadnienie w przesłance ochrony zdrowia.

Gwarancje poszanowania niedzieli i dni świątecznych jako dni wolnych od pracy znajdują się w różnych źródłach prawa ${ }^{56}$. Wykaz „dni wolnych od pracy” trzeba odróżnić od katalogu ,dni ustawowo wolnych od pracy”, aczkolwiek ten drugi mieści się z reguły w tym pierwszym. W Polsce „dniami ustawowo wolnymi od pracy” są zasadniczo dni będące świętami religijnymi Kościoła Rzymskokatolickiego, lecz część z nich pokrywa się

55 Zob. wyroki Naczelnego Sądu Administracyjnego z dnia 26 kwietnia 2018 r.: II OSK 1499/16, LEX nr 2511421 oraz OSK 1504/16, LEX nr 2505698.

56 Zarzycki 2006, 99 i n. 
też ze świętami religijnymi innych wspólnot chrześcijańskich ${ }^{57}$. W myśl przepisów ustawy z dnia 18 stycznia $1951 \mathrm{r}$. o dniach wolnych od pracy ${ }^{58}$ dniami wolnymi od pracy są święta wymienione w jej art. 1 pkt 1, a także niedziele (art. 1 pkt 2). Natomiast w odniesieniu do wiernych Kościoła Katolickiego wykaz dni wolnych od pracy określa także art. 9 Konkordatu między Stolicą Apostolską i Rzecząpospolitą Polską ${ }^{59}$. Dopuszczalność ograniczenia lub zawieszenia prawa do dnia świątecznego może utrudniać realizację obowiązków religijnych. W literaturze przedmiotu podkreśla się, że regulacje prawne dotyczące świąt religijnych mają na celu zapewnienie wiernym warunków do spełnienia powinności konfesyjnych ${ }^{60}$. Warto wspomnieć, że w warunkach zwyczajnego funkcjonowania państwa dopuszcza się również zawieszenie prawa do dnia świątecznego, co wynika $\mathrm{z}$ regulacji ustawy z dnia 26 czerwca 1974 r. - Kodeks pracy ${ }^{61}$.

\section{WNIOSKI KOŃCOWE}

Podsumowując należy stwierdzić, że ochrona wolności sumienia i religii w stanie zagrożenia epidemicznego, stanie epidemii i stanie klęski żywiołowej opiera się na zróżnicowanych gwarancjach prawnych. Zasadnicza różnica sprowadza się do tego, że wolność z art. 53 Konstytucji zaliczona została do grupy praw niederogowalnych w stanie klęski żywiołowej. Takiego przymiotu nie ma wolność sumienia i religii w stanie zagrożenia epidemicznego i stanie epidemii, gdyż w odniesieniu do tych instytucji prawnych w ogóle nie przewidziano takiej kategorii praw człowieka. Inną sprawą jest zaś to, że założenie ustrojowe o niederogowalności wolności sumienia i religii w stanie klęski żywiołowej realizowane jest jedynie częściowo ze względu na naturę prawną tej wolności. Wzmocnie-

57 Pietrzak 2010, 241.

58 Ustawa z dnia 18 stycznia 1951 r. o dniach wolnych od pracy, tekst jedn. Dz. U. z 2020 r., poz. 1920.

59 Konkordat między Stolicą Apostolską i Rzecząpospolitą Polską podpisany dnia 28 lipca 1993 r., Dz. U. z 1998 r. Nr 51, poz. 318.

60 Mezglewski 2011, 227.

${ }_{61}$ Ustawa z dnia 26 czerwca 1974 r. - Kodeks pracy, tekst jedn. Dz. U. z 2020 r., poz. 1320 . 
nie realizacji założenia niederogowalności wymaga bliższego określenia na czym polega istota prawa lub wolności konstytucyjnej o charakterze niederogowalnym ${ }^{62}$. Treść odnoszącej się do tego ustawy skłania do poglądu o jedynie częściowym zabezpieczeniu wolności z art. 53 Konstytucji RP w tym stanie nadzwyczajnym. Pozytywny wpływ na zakres ochrony wolności sumienia i religii w stanie klęski żywiołowej ma natomiast niewątpliwie klauzula antydyskryminacyjna, a także wymóg przestrzegania zasady proporcjonalności wprowadzanych ograniczeń. Warto natomiast rozważyć wzmocnienie gwarancji prawnych wolności sumienia i religii poprzez wprowadzenie odpowiednich unormowań do ustawy o stanie klęski żywiołowej w ramach wyjątków wobec ograniczeń innych praw i wolności konstytucyjnych ze względu na naturę prawną tej wolności. Zmiany w prawie powinny uwzględniać przede wszystkim hierarchiczność systemu prawa i jego założeń, a także postulat efektywności regulacji w drodze do osiągnięcia danego celu ${ }^{63}$.

Wolność z art. 53 Konstytucji RP nie została wprost wymieniona w grupie praw i wolności, które w stanie zagrożenia epidemicznego oraz w stanie epidemii mogą zostać zawieszone na podstawie ustawy o zapobieganiu oraz zwalczaniu zakażeń i chorób zakaźnych u ludzi. Należy jednak stwierdzić, że część uprawnień szczegółowych będzie trudna do realizacji z uwagi na ograniczenia w sferze innych praw i wolności konstytucyjnych. Przyznanie przymiotu niederogowalności wolności sumienia i religii zasadniczo należy do ustrojodawcy, lecz wydaje się, iż nie ma przeszkód, aby prawodawca zwykły przyjął takie założenie na gruncie ustawowym, co stanowiłoby działanie in favorem libertatis. Byłoby to ponadto spójne $\mathrm{z}$ wysoką pozycją ustrojową wolności sumienia i religii w prawie polskim. Ograniczenie wolności z art. 53 Konstytucji RP w stanie zagrożenia epidemicznego oraz w stanie epidemii może nastąpić jedynie na zasadach ogólnych. Konieczne jest więc uwzględnienie standardów określonych w art. 31 ust. 3 i art. 53 ust. 5 Konstytucji RP.

Warto ponadto rozważyć wprowadzenie dodatkowych gwarancji o charakterze pozytywnym w sferze ochrony wolności sumienia i religii, które mogą zostać wpisane do ustawy o zapobieganiu oraz zwalczaniu

\footnotetext{
62 Jabłoński 2016, 189.

63 Stanisz 2021, 160-161.
} 
zakażeń i chorób zakaźnych u ludzi lub innych ustaw. Sam brak wyliczenia tej wolności w katalogu ograniczeń dopuszczalnych w stanie zagrożenia epidemicznego lub w stanie epidemii wydaje się być zabiegiem niewystarczającym. Należy przy tym poszukiwać rozwiązań kompromisowych, aby nie doprowadzać do wrażenia, że faworyzowane są osoby o światopoglądzie religijnym. Uwaga ta dotyczy także szerszego problemu ochrony praw i wolności konstytucyjnych w stanie zagrożenia epidemicznego i w stanie epidemii. Wydaje się, że obecny stan prawny nie odpowiada przedstawionym założeniom.

\section{BIBLIOGRAFIA}

Bielecki, Marek. 2021. „Ograniczenia wolności religijnej w okresie pandemii”. W: Transformacje prawa polskiego $w$ dobie epidemii COVID-19, red. Przemysław Szustakiewicz, Mariusz Wieczorek, 37-57. Warszawa: UTH Radom.

Bosek, Leszek. 2021a. „Anti-epidemic emergency regimes under Polish law in Comparative, Historical and Jurisprudential Perspective". European Journal of Health Law 28: 113-141.

Bosek, Leszek. 2021b. „Art. 2”. W: Ustawa o zapobieganiu oraz zwalczaniu zakażeń $i$ chorób zakaźnych u ludzi. Komentarz, red. Leszek Bosek, 39-65. Warszawa: C.H. Beck.

Bosek, Leszek. 2021c. „Art. 46”. W: Ustawa o zapobieganiu oraz zwalczaniu zakażeń i chorób zakaźnych u ludzi. Komentarz, red. Leszek Bosek, 739-777. Warszawa: C.H. Beck.

Brzeziński, Michał. 2007. Stany nadzwyczajne w polskich konstytucjach. Warszawa: Wydawnictwo Sejmowe.

Canestrini, Nicola. 2020. „Covid-19 Italian emergency legislation and infection of the rule of law". New Journal of European Criminal Law 23: 116-122.

Dyda, Konrad, Marcin Olszówka. 2020. „Analiza konstytucyjności ograniczeń w korzystaniu z wolności religii podczas pandemii koronawirusa w Polsce". Studia z Prawa Wyznaniowego 23: 441-469.

Działocha, Kazimierz. 2005. „Artykuł 233”. W: Konstytucja Rzeczypospolitej Polskiej. Komentarz, T. 4, red. Leszek Garlicki. Warszawa: Wydawnictwo Sejmowe.

Garlicki, Leszek. 2007. Polskie prawo konstytucyjne. Zarys wykładu. Warszawa: Liber. 
Jabłoński, Mariusz. 2016. „Ograniczenie konstytucyjnych wolności i praw osobistych w czasie trwania stanów nadzwyczajnych". Acta Universitatis Wratislaviensis. Przeglad Prawa i Administracji 106: 173-191. DOI: 10.19195/0137-1134.106.16.

Kardas, Piotr. 2020. „Konstytucyjne podstawy rozstrzygania kolizji obowiązków i konfliktów dóbr w czasie epidemii". Palestra 6: 7-23.

Kazimierczuk, Marcin. 2005. „Zasady funkcjonowania państwa podczas stanu klęski żywiołowej w III RP”. Studia Prawnoustrojowe 4: 85-94.

Kitowska, Wioleta, Małgorzata Stępień, Magdalena Rosińska, Katarzyna Szmulik, Małgorzata Jamsheer-Bratkowska, Paweł Budziosz, Małgorzata Sadkowska-Todys. 2020. „Moduł COVID-19 w SRWE - zastosowanie i wykorzystanie w nadzorze epidemiologicznym oraz raportowaniu do instytucji międzynarodowych”. Przegląd Epidemiologiczny 3: 416-431.

Kurzępa. Elżbieta. 2021. „Stan epidemii a stan klęski żywiołowej - rozważania w kontekście bezpieczeństwa państwa”. Przeglad Prawa Publicznego 5: $5-21$.

Maroń, Grzegorz. 2021. „Polskie prawodawstwo ograniczające wolność religijną w okresie pandemii koronawirusa SARS-CoV-2 a standardy państwa prawa wybrane zagadnienia”. Przeglad Prawa Publicznego 1: 33-49.

Mezglewski, Artur. 2011. „Kult publiczny”. W: Artur Mezglewski, Henryk Misztal, Piotr Stanisz, Prawo wyznaniowe, 223-232. Warszawa: C.H. Beck.

Morawski, Filip. 2020. „Zakaz przemieszczania się w związku z pandemią COVID-19 w świetle konstytucyjnego prawa do poruszania się". Przegląd Prawa Publicznego 9: 7- 17.

Ożóg, Michał. 2016. „Wolność sumienia i religii w stanach nadzwyczajnych w polskim systemie prawnym". Forum Prawnicze 4: 48-67.

Pałka, Katarzyna. 2018. „Świadczenia zdrowotne związane z chorobami zakaźnymi, w tym obowiązkowe i zalecane szczepienia". W: System Prawa Medycznego, T. 2: Szczególne świadczenia zdrowotne, red. Leszek Bosek, Agata Wnukiewicz-Kozłowska, 603-624. Warszawa: C.H. Beck.

Paśnik, Jerzy. 2020. „Kilka refleksji o regulacji stanu epidemii jako sui generis pozakonstytucyjnego stanu nadzwyczajnego". Przeglad Prawa Publicznego 11: 69-85.

Pietrzak, Michał. 2010. Prawo wyznaniowe. Warszawa: Lexis Nexis.

Prokop, Krzysztof. 2005. Stany nadzwyczajne w Konstytucji Rzeczypospolitej Polskiej z dnia 2 kwietnia 1997 r. Białystok: Temida 2.

Ruczkowski, Piotr. 2002. „Artykuł 3”. W: Stan klęski żywiołowej. Komentarz. Warszawa: LEX/el. 
Skrzydło, Wiesław. 2013. Konstytucja Rzeczypospolitej Polskiej. Komentarz. Warszawa: Wolters Kluwer.

Stanisz, Piotr. 2021. „Ograniczenia wolności kultu religijnego w czasie pandemii COVID-19: między konstytucyjnością a efektywnością". Przegląd Sejmowy 3 (164): 143-165.

Steinborn, Sławomir. 2016. „Artykuł 233”. W: Konstytucja RP. Tom II. Komentarz art. 87-243, red. Marek Safjan, Leszek Bosek, 1629-1633. Warszawa: C.H. Beck.

Trociuk, Stanisław. 2021. „Wolność uzewnętrzniania religii”. W: Prawa i wolności w stanie epidemii. Warszawa: LEX/el.

Tuleja, Piotr. 2020. „Pandemia COVID-19 a konstytucyjne stany nadzwyczajne”. Palestra 9: 5-20.

Wilk, Jakub. 2012. „Wprowadzanie ograniczeń praw i wolności w stanie klęski żywiołowej”. Acta Erasmiana III. Prace Prawnicze 3: 145-161.

Winczorek, Piotr. 2008. Komentarz do Konstytucji Rzeczypospolitej Polskiej $z$ dnia 2 kwietnia 1997 roku. Warszawa: Liber.

Wojtyczek, Krzysztof. 1999. Granice ingerencji ustawodawczej w sferę praw człowieka w Konstytucji RP. Kraków: Zakamycze.

Zarzycki, Zdzisław. 2006. „Konkordatowe i pozakonkordatowe gwarancje poszanowania niedzieli i dni świątecznych jako dni wolnych od pracy". Krakowskie Studia Międzynarodowe 3: 99-117.

Zoll, Andrzej. 2014. „Charakter prawny klauzuli sumienia”. Medycyna Praktyczna 1: 99-103.

Zubik, Marek. 2021. Prawo konstytucyjne wspótczesnej Polski. Warszawa: C.H. Beck. 
